\title{
Configurational Analysis of Contemporary Korean-Style Houses Regarding the Expression of Their Koreanity
}

\author{
Dongkuk Chang and Jaechoon Shim \\ Professor, School of Architecture, Chosun University \\ Professor, School of Architecture, Gwangju University
}

http://dx.doi.org/10.5659/AIKAR.2011.13.4.3

\begin{abstract}
This research focuses on how the 'Koreanity' inherent in many traditional Korean houses of the upper class is expressed in contemporary 'Korean-style' houses, and how aspects regarded as configurational characteristics of traditional houses are expressed in them. Three types of Korean house (traditional upper class, contemporary Korean-style and contemporary architect) are quantitatively analysed using the space syntax method to investigate of the spatial configuration and their syntactic properties. The research results show that the spatial configuration of traditional houses is more integrated than that of contemporary houses. Furthermore, contemporary Korean-style houses are similar to architect's houses in terms of their spatial configurations. The configurational analyses reveal that the way in which spatial configuration is expressed in contemporary Korean-style houses is significantly different from traditional Korean houses. This result is in direct contrast to the architects' claim that their houses maintain the configurational chracteristics of traditional Korean houses.
\end{abstract}

\section{Keywords: Koreanity, Traditional Korean Houses, Contemporary Korean-style Houses, Contemporary Architects' Houses, Space Syntax}

\section{INTRODUCTION}

\subsection{Research aims}

The Buyeo National Museum designed by Kim Soo-Geun in the 1960s brought about a heated debate regarding the architectural expression of Koreanity in contemporary Korean architecture. Subsequently, the topic of Korean traditions in contemporary Korean houses led to more architectural design experiments because of the great attention to and support of traditional culture that lasted up until the 2000s, with a period of peak growth in the 1980s.

Attempts regarding the incorporation of traditional Korean architecture into contemporary architecture began with the examination of various traditional Korean ideologies, and were implemented based on field surveys as well as research on ancient buildings such as royal palaces, temples, local Confucian schools and upper class housing. Moreover, the depth of research was deepened by research conducted on individual building elements,

Correspondence to: Dongkuk Chang, Professor School of Architecture, Chosun University

375 Seosuk-dong, Dong-ku, Gwangju, South Korea, 501-759

Tel: +8262 2307149 e-mail : cdass@chosun.ac.kr

This study was supported by research fund from Chosun

University, 2009

Acknowledgements. I wish to thank Back-whan Kim for his help in producing the final case studies.

This is an Open Access article distributed under the terms of the Creative Commons Attribution Non-Commercial License (http://creativecommons. org/licenses/by-nc/3.0/) which permits unrestricted non-commercial use, distribution, and reproduction in any medium, provided the original work is properly cited. such as spatial elements, materials, decorative design and the elevations of traditional Korean architecture.

The results of these studies on 'contemporary Korean-style architecture' which have specifically expressed Koreanity in contemporary buildings, have began to attract attention ${ }^{1}$. Many contemporary Korean architects have incorporated three ways of expressing Koreanity in their design: firstly traditional design techniques, for example the shape of a traditional roof; secondly the use of traditional building materials, such as wood, brick and roof tiles; finally space composition, such as the inclusion of a courtyard in the design and distinctive use of spatial configuration design. This study focuses on the latter means of Koreanity expression, because the spatial configuration analysis method of space syntax is very helpful to figure out common factors in many case study houses, as well as an objective and scientific methodology (Huh and Chung, 2001).

However, there is a limit to the previous research on the spatial configurational aspect of Koreanity implemented in contemporary Korean-style architecture. Unfortunately it could not be accepted as an objective result to be presented in a descriptive form regarding the types of spatial configuration. This is because it was not verified scientifically using a proper frame of analysis, making it impossible to compare the analysis results mutually and objectively. Therefore, contemporary Korean-style houses and 'contemporary architects' houses $^{\prime 2}$ are compared mutually from the viewpoint of spatial

\footnotetext{
${ }^{1}$ Contemporary Korean-style architecture is contemporary architecture in which the architects have mentioned that they expressed architectural characteristics unique to traditional Korean architecture.

${ }^{2}$ Contemporary architects' houses mean contemporary houses with the expression of a design concept unique to the architect without mentioning any expression of Koreanity.
} 
configuration.

Based on the configurational analyses, the following issues will be examined. That is, what are the representative characteristics of spatial configuration inherent to traditional Korean houses? How far does is Koreanity similar

with that expressed in contemporary Korean-style houses as an aspect of spatial configuration of these traditional Korean houses? And, what is the difference or similarity between contemporary Korean-style houses and contemporary architects' houses with regards to spatial configurations?

\subsection{Scope and method of the research (1) Houses in case study}

We investigated three different types of Korean house: 12 traditional Korean houses, 12 contemporary Korean-style houses, and 12 contemporary architects' houses (Table 1). For determining a clear difference regarding Koreanity, the 'space syntax' method of configurational analysis is employed.

The criteria of selecting the 12 units of traditional Korean houses as target houses for this study has been thoroughly discussed in many existing studies with excellent preservation value or sufficient academic data. Due to the fact that the degree of expression of traditional characteristics of Hanok (traditional Korean houses) on each house is different according to the social status of the owner (nobleman, middleman, common people and servants during the Joseon Dynasty), relatively well preserved upper class houses of that

Table 1. Traditional Korean houses, contemporary Korean-style houses and contemporary architects' houses

\begin{tabular}{|c|c|}
\hline Traditional Korean houses & Construction year \\
\hline Gangreung Seongyojang & Beginning of the 17 th century \\
\hline Goisan Kim, Gi-Eung house & 19th century \\
\hline Naju Hong, Gi-Eung house & $\begin{array}{l}\text { Main building of a house:1892, Men's } \\
\text { quarters:1904 }\end{array}$ \\
\hline Namwon Mongsimjae & 18th century \\
\hline Dokrakdang & Year 1532 \\
\hline Asan Geonjae old house & Late period of Joseon \\
\hline $\begin{array}{l}\text { Andong Euiseong Kim's Head } \\
\text { Family house }\end{array}$ & 15 th century \\
\hline Chungon house & 18th century \\
\hline Jeongeub Kim, Dong-Su house & 1790 \\
\hline Chungwon Yu, Gye-Hwa house & 1866 \\
\hline Hamyang Chung, Byeong-Ho house & 1570 \\
\hline Hoideok Dongchun-Dang & 1653 \\
\hline Contemporary Korean-style houses & Construction year \\
\hline Gagabuli & 1995 \\
\hline Guinheon & 1999 \\
\hline Subaekdang & 1999 \\
\hline Sujoldang & 1993 \\
\hline Monghakjae & 1994 \\
\hline Ilsan 22393 HOUSE & 1996 \\
\hline Ilsan 22412 HOUSE & 1997 \\
\hline Imgeodang & 1999 \\
\hline Pyeongsimjeong & 1999 \\
\hline Hakeuije & 2002 \\
\hline Hanhojae & 1998 \\
\hline Hoyujae & 2000 \\
\hline Contemporary architects' houses & Construction year \\
\hline Goigok-Dong Lhouses & 2001 \\
\hline House weaving words & 2010 \\
\hline P - HOUSE & 2010 \\
\hline
\end{tabular}

\begin{tabular}{c|l}
\hline Lian houses & 2007 \\
\hline Vector house & 2010 \\
\hline Bunongru & 2001 \\
\hline Sangyeonjae & 2008 \\
\hline S-HOUSE 01 & 2007 \\
\hline Wolcheonjae & 2009 \\
\hline Pangyo Chapel House & 2010 \\
\hline Villa To project & 2010 \\
\hline Sudong-Myeon houses & 2001 \\
\hline
\end{tabular}

period were selected.

Contemporary Korean-style houses have been selected, based on the fact that they expressed Koreanity through the positive introduction of spatial configuration characteristics of traditional Korean houses by the architects themselves. These contemporary Korean-style houses are regarded a result of the culturalisation of traditional residential culture unique to Korea into contemporary residences, and were mainly positively attempted after the 1990s.

Of course, it is a well-known fact that the implementation of this Koreanity into contemporary houses were a result of the bad side effects of indiscriminate applications of western residential culture, which were popularised during the last radical period of modernisation from 1960s to 1990s. In particular, it can be said to be our social self-consciousness against uniform popularisation of an individual residential culture, while also losing the traditional residential culture unique to Korea. Architects themselves portrayed that their houses positively expressed a spatial configuration of Koreanity, with a view to the composition relationship between the courtyard and the building, and the configurational characteristics of each space.

As for contemporary architects' houses, houses that had no mention of an architectural concept to express the Koreanity of traditional Korean houses were selected among the works introduced in professional architecture magazines, such as Architectural Culture, SPACE and PLUS published in Korea. Considering that Korean traditional houses were upper class houses, contemporary architects' houses were selected focusing on relatively large detached houses designed by contemporary Korean architects. They were mostly built in recent years and were described by the architects as having a distinctive design concept.

\section{(2) Configurational analysis method of space syntax}

A 'convex map' was prepared by using the MoonSpacer ${ }^{3}$ program developed by this research team for the analysis of the spatial configuration of the target houses. A convex map expresses all the space in a two dimensional surface of the convex space, and by converting the connection relationship between the surfaces into a graph, it shows the connection relationship of the space in a quantitative form ${ }^{4}$. The spatial configurations were compared mutually per house (Figs. 1, $2 \& 3$ ). Syntactic variables, which are mainly utilised in this research, can be induced through a convex map analysis and by utilising configurational factors, such as global and local integration and mean depth.

\footnotetext{
${ }^{3}$ Chang, D.K. and Park, J.H., MoonSpacer ${ }^{\mathrm{TM}}$, Korea Copyright Commission, Registration number: 201001129002116

${ }^{4}$ Convex Map preparation and theoretical background shall refer to the following references. Hillier (1996) and Hanson (1998).
} 
A global integration is a generalisation used for possible comparison of the topology between spaces, using average spatial depth regardless of the size and form of the space. This illustrates space configurational characteristics that all spaces within the spatial system interact mutually as the relationship between all spaces and all other spaces. In contrast, local integration only shows the characteristics of partial relationship between all spaces within

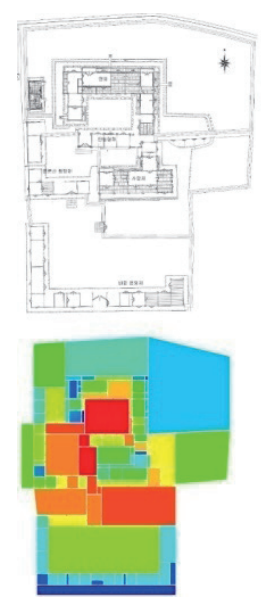

a) Goisan Kim, Gi-Eung house
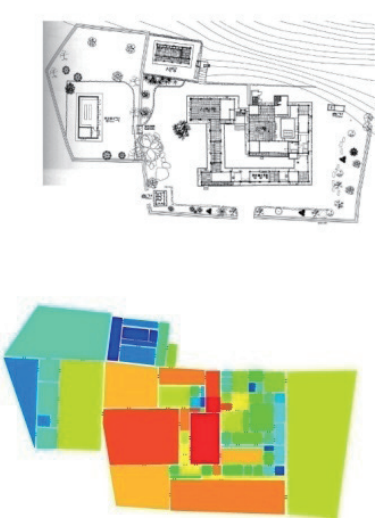

b) Andong Euiseong Kim's family house
Figure 1. Traditional Korean houses

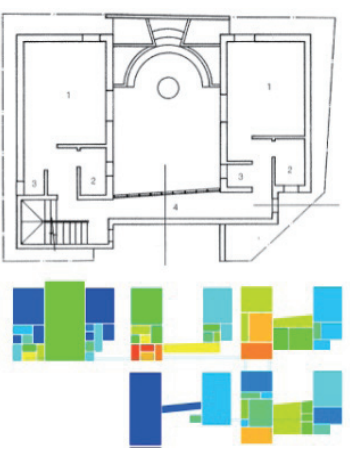

a) Gagabuli
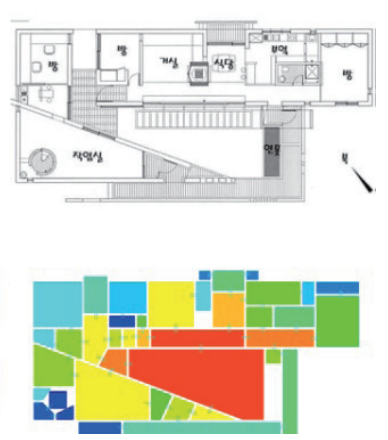

b) Pyeongsimjeong
Figure 2. Contemporary Korean-style houses
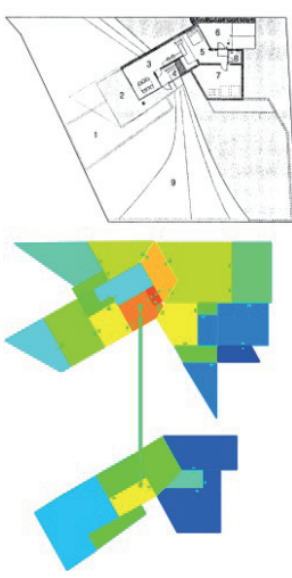

a) Villa Topoject

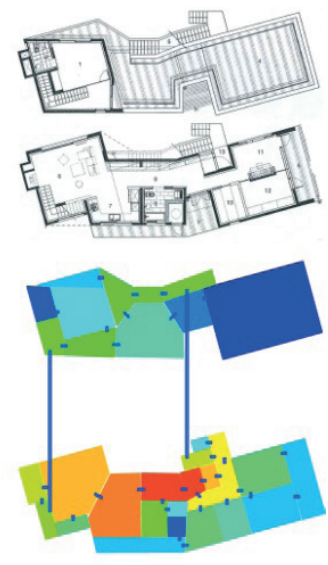

b) Vector house
Figure 3. Contemporary architects' houses the whole space as an integration only considering neighbouring spaces (for example, space connected up to the third) and a specific space.

The integration is coloured from red to dark blue, according to the degree of the value, red denotes the highest and dark blue the lowest value (Figs. 1, 2 \& 3). Figs. 1, 2 and 3 show the results of the analysis of a convex map of only two houses per type of house among the three types of houses, due to the limitations of space. Mean spatial depth is expressed in averages by calculating the spatial depth for reaching up to all other spaces within the system in a specific space. If it is expressed in a graphical form, it indicates the number of connection lines reaching all points within the system from a specific point. ${ }^{5}$

\section{RESEARCH TRENDS REGARDING KOREANITY IN CONTEMPORARY KOREAN HOUSES}

Research on Koreanity in contemporary Korean houses began in full scale, together with an increase in social attention to the study of Korean cultural heritage, in the 1970s. Of course, discussion of Koreanity regarding the Buyeo National Museum of Kim SooGeun in the 1960s was the momentum for hot debates about expression of Koreanity in Korean architecture, as mentioned earlier. However, it can be stated that it was only from the 1980s that academically profound research was systematically conducted. With an understanding of this historical context, the research trends and limits of existing studies will be presented by classifying research topics regarding Koreanity in contemporary architecture into house type, building material, decorative design and spatial configuration fields.

An example of exemplary research on house types and Koreanity is a spatial research on the configurational change of Korean houses conducted by Noh (2000). He periodically took a view of changes of spatial configuration of houses ranging from traditional Korean houses to various types of house since the 1960s. Using space syntax, the changes in spatial configuration of a total of 104 houses were analysed, including traditional Korean houses, urban type traditional Korean house, standard houses, general detached houses, architect's houses and apartments. Noh showed that the spatial depth of traditional Korean houses is as a whole shallow, and therefore it has characteristics of spatial configuration with generally high integration.

On the other hand, his research showed that contemporary houses have been changed into privately segregated areas with deeper spatial depth. In addition, while the living room, sitting room, reception room and courtyard showed characteristics of becoming private in a structure with a deep depth of space, he showed over the course of his work that the spatial depth of the kitchen gradually became shallower and emerged as a central space of the house. In the case of contemporary architect's houses, it showed that the division of private and public space became clearer.

Noh's research results support the findings suggested in this study in various aspects. But we took a more in-depth approach regarding the differences in the method or expression of Koreanity expressed in contemporary houses. Unfortunately, Noh's study was a little

\footnotetext{
${ }^{5}$ Refer to the following literature for more detail regarding the calculation of an integration: Chang, Kim, Moon, and Park (2007).
} 
lacking in the aspect of characteristics of spatial configuration of traditional houses, and this is therefore a key topic of this study.

Kim (2003) studied how Koreanity appeared in Korean contemporary common residence plans by dividing them into social culture (traditional ideology, spatial configuration in the concept of community and expression of thr locality of the region), spatial configuration (introduction of media space and characteristics of variable spatial configuration) and decorative design characteristics (traditional structures, interior patterns and colours). The objective of his study was to deduce the types of method of expression of Koreanity appearing in contemporary common residence plans, and to suggest ways of applying these in the future.

For the second research topic, we focused on the materials and decorative designs of residential architecture. As a representative study, Oh (2007) carried out a study on the impact of the building materials used for traditional houses on the formation of an internal and external sense of space, because Koreanity in the aspect of building materials and the decorative design used has a significant effect that can be directly delivered to the users. His research demonstrated that certain material property characteristics such as glass, wood, stone, block, brick and metal materials, which are prevalent in contemporary architecture, were fully utilised as methods expressing proportion of horizontal/vertical space within the material property of traditional architecture.

The third research topic regards the spatial configuration of houses, such as the study of Lee (1998). He used theories regarding space philosophy to find context and meaning in the spaces of traditional Korean architecture by catogorising them into spatial separation, spatial ranking, spatial continuity, space integration, spatial medium and the spatial centre of architectural design principles.

Research by $\mathrm{Na}$ (2004) focused on changes in the internal spatial configuration of apartments and contemporary architect's houses, by studying their residential environments. Differences were found in the residential culture by analysing these houses with space syntax and by classifying the overall characteristics of the spatial organisation. Spatial configuration, changes to central spaces, changes to dining room/kitchen areas, changes to the sitting room and social spatial configuration were also compared. Currently, various research studies on the relationship between spatial configuration and social elements regarding traditional Korean houses are being conducted.

Despite various research studies in the abovementioned areas, previous studies on architectural elements expressing the Koreanity of traditional Korean architecture have limits in that the studies were mainly composed of the visual expression of traditional buildings. In addition, regarding the aspect of Koreanity in contemporary architecture, it is the current reality that research is limited to design techniques, and the materials or space, which can also provide traditional images. In particular, the majority of research has focused on types of external spatial configurations, such as flat forms or the courtyard, elevation materials and decorative designs and research results classified in detail by the establishment of a methodological standard of design according to spatial characteristics.
Table 2. Spatial configuration factors (Mean) of traditional Korean houses

\begin{tabular}{|c|c|c|c|c|}
\hline $\begin{array}{c}\text { Traditional Korean } \\
\text { houses }\end{array}$ & $\begin{array}{l}\text { Number } \\
\text { of space }\end{array}$ & $\begin{array}{c}\text { Global } \\
\text { integration }\end{array}$ & $\begin{array}{c}\text { Local } \\
\text { integration }\end{array}$ & Spatial depth \\
\hline $\begin{array}{l}\text { Gangreung } \\
\text { Seongyojang }\end{array}$ & 121 & 0.985197 & 1.626491 & 5.690220 \\
\hline $\begin{array}{l}\text { Goisan Kim, Gi- } \\
\text { Eung house }\end{array}$ & 102 & 0.814644 & 1.767860 & 6.254125 \\
\hline $\begin{array}{c}\text { NajuHong, Gi-Eung } \\
\text { house }\end{array}$ & 72 & 0.959565 & 1.644007 & 5.036385 \\
\hline $\begin{array}{c}\text { Namwon } \\
\text { Mongsimjae }\end{array}$ & 76 & 1.145747 & 1.744720 & 4.455439 \\
\hline Dokrakdang & 80 & 0.768698 & 1.510070 & 6.262658 \\
\hline $\begin{array}{l}\text { Asan Geonjae old } \\
\text { house }\end{array}$ & 88 & 1.130284 & 1.575103 & 4.654911 \\
\hline $\begin{array}{l}\text { Jeongeub Kim, } \\
\text { Dong-Su house }\end{array}$ & 80 & 0.950685 & 1.704954 & 5.189240 \\
\hline $\begin{array}{c}\text { Andong Euiseong } \\
\text { Kim's family old } \\
\text { house }\end{array}$ & 74 & 0.794484 & 1.478632 & 5.922621 \\
\hline $\begin{array}{c}\text { Chung, On teacher } \\
\text { house }\end{array}$ & 78 & 0.893973 & 1.497064 & 5.508158 \\
\hline $\begin{array}{l}\text { Chungwon Yu, } \\
\text { Gye-Hwa house }\end{array}$ & 50 & 1.287772 & 1.866457 & 3.596735 \\
\hline $\begin{array}{l}\text { Hamyang Chung, } \\
\text { Byeong-Ho house }\end{array}$ & 104 & 0.808176 & 1.624504 & 6.395071 \\
\hline $\begin{array}{l}\text { Hoideok Dongchun- } \\
\text { Dang }\end{array}$ & 82 & 0.752880 & 1.50584 & 6.357121 \\
\hline Mean & 84 & 0.927687 & 1.624474 & 5.548732 \\
\hline
\end{tabular}

Table 3. Spatial configuration factors (Mean) of contemporary Koreanstyle houses

\begin{tabular}{c|c|c|c|c}
\hline $\begin{array}{c}\text { Contemporary } \\
\text { Korean-style houses }\end{array}$ & $\begin{array}{c}\text { Number } \\
\text { of space }\end{array}$ & $\begin{array}{c}\text { Global } \\
\text { integration }\end{array}$ & $\begin{array}{c}\text { Local } \\
\text { integration }\end{array}$ & Spatial depth \\
\hline Monghakjae & 81 & 0.677932 & 1.347768 & 6.923148 \\
\hline Ilsan 22393 & 41 & 0.708246 & 1.171898 & 5.370732 \\
\hline Imgeodang & 70 & 0.595903 & 1.269157 & 7.440166 \\
\hline Pyeongsimjeong & 40 & 0.830121 & 1.286198 & 4.721795 \\
\hline Sujoldang & 38 & 0.621254 & 1.201976 & 5.830726 \\
\hline Hanhojae & 42 & 0.515668 & 1.236311 & 7.111498 \\
\hline Hoyujae & 67 & 0.451930 & 1.209283 & 9.220262 \\
\hline Hakeuijae & 65 & 0.653679 & 1.291843 & 6.762500 \\
\hline Gagabuli & 61 & 0.514953 & 1.199361 & 8.078689 \\
\hline Subaekdang & 50 & 0.821236 & 1.546091 & 5.316735 \\
\hline Ilsan 22412 & 60 & 0.514371 & 1.183558 & 8.000000 \\
\hline Guinheon & 20 & 0.872341 & 1.390060 & 3.494737 \\
\hline Mean & 53 & 0.626277 & 1.274611 & 6.892536 \\
\hline
\end{tabular}

Table 4. Spatial configuration factor (Mean) of contemporary architects' houses

\begin{tabular}{c|c|c|c|c}
\hline $\begin{array}{c}\text { Contemporary } \\
\text { architects' houses }\end{array}$ & $\begin{array}{c}\text { Number } \\
\text { of space }\end{array}$ & $\begin{array}{c}\text { Global } \\
\text { integration }\end{array}$ & $\begin{array}{c}\text { Local } \\
\text { integration }\end{array}$ & Spatial depth \\
\hline $\begin{array}{c}\text { Goigok-Dong L } \\
\text { houses }\end{array}$ & 32 & 0.667661 & 1.158357 & 5.173387 \\
\hline $\begin{array}{c}\text { House weaving } \\
\text { words }\end{array}$ & 21 & 0.889718 & 1.294521 & 3.571429 \\
\hline P-house & 32 & 0.730636 & 1.382830 & 4.816532 \\
\hline Lian houses & 28 & 0.546883 & 1.198690 & 5.719577 \\
\hline Vector house & 33 & 0.574001 & 1.121179 & 5.782197 \\
\hline Bunongru & 32 & 0.612538 & 1.181186 & 5.530242 \\
\hline Sangyeonjae & 25 & 0.649725 & 1.033411 & 4.833333 \\
\hline $\begin{array}{c}\text { Seongbuk-Dong } \\
\text { houses }\end{array}$ & 46 & 0.658108 & 1.370495 & 5.931401 \\
\hline Wolcheonjae & 46 & 0.548675 & 1.233324 & 6.868599 \\
\hline Pangyo chapel house & 37 & 0.581623 & 1.064782 & 6.096096 \\
\hline Villa Topoject & 34 & 0.705973 & 1.189375 & 5.064171 \\
\hline $\begin{array}{c}\text { Sudong-Myeon } \\
\text { houses }\end{array}$ & 53 & 0.719699 & 1.395155 & 5.835268 \\
\hline Mean & 35 & 0.650854 & 1.232107 & 5.582925 \\
\hline
\end{tabular}


Therefore in this study, research on Koreanity in the aspect of spatial configuration was conducted using space syntax, which can scientifically and quantitatively compare traditional Korean houses by interpreting spatial configuration techniques. By utilising this methodology, it becomes possible to verify whether Koreanity was realised as intended by the architects in the aspect of spatial configuration in contemporary Korean-style houses. In order to re-confirm whether Koreanity was realised in the aspect of spatial configuration in contemporary Korean-style houses, the space configurational factors of contemporary architects' houses are compared and analysed.

\section{ANALYSIS OF THE SPATIAL CONFIGURATION OF TARGET HOUSES}

\subsection{Configuration analyses of houses}

For the case study, the spatial configuration of 12 of each type of house - traditional Korean houses (Table 2), contemporary Koreanstyle houses (Table 3) and contemporary architects' houses (Table 4) - were analyzed with convex mapping (Figs. 1, 2 \& 3).

Of particular importance to note is that we confirm the actual features of Koreanity of contemporary Korean-style houses by comparing and analyzing their spatial configuration with that of contemporary architects' houses. It can be said that Koreanity was specifically expressed where differences in spatial configuration are clear between the two groups and where spatial configuration of the contemporary Korean-style houses is similar to that of traditional Korean houses. Conversely, it cannot be said that Koreanity was expressed in contemporary Korean-style houses as the architects intended where there is no difference in spatial configuration between the two groups and they are mutually similar.

The average number of space in traditional Korean houses is 84 (Table 2), and it is noted that it is higher when compared to contemporary Korean-style houses (53) (Table 3), and contemporary architects' houses (35) (Table 4). However, the mean of the global integration is 0.927687 for traditional Korean houses while it is 0.626277 for contemporary Korean-style houses and 0.650854 for contemporary architects' houses, and thus shows a large difference. The fact that the global integration of traditional Korean houses is higher than other house types means that it is more efficient in its accessibility than the other types of house.

In particular, the fact that the global integration is higher despite the number of spaces in traditional Korean houses being far higher than the houses of the other two types can be interpreted to prove that the spatial configuration of traditional Korean houses is more integrated than that of the other types of houses. Local integration also shows a similar trend close to the figures of the global integration.

In reviewing the differences in mean spatial depth, no difference was found between traditional Korean houses (5.548732) and contemporary architects' houses (5.582925) but it is noted that contemporary Korean-style houses are about 1.3 times deeper compared to houses of other types. In particular, despite the average spatial depth of contemporary Korean-style houses being about 1.3 times deeper than contemporary architects' houses, the global integration has very little difference. But it is also necessary to note that the global integration of contemporary architects' houses are a slightly higher.
Differences in the spatial configuration appearing in the houses of these two types can be interpreted in that contemporary Koreanstyle houses are deeper in spatial depth compared to contemporary architects' houses and are slightly lower in the global integration. As a direct result of these differences, we focused on the fact that it is lower overall in the global integration for most of the spaces except the courtyard of contemporary Korean-style houses. This is because the element that is mentioned as being the most important expression of Koreanity in contemporary Korean-style houses in terms of spatial configuration is the courtyard. It is also noted that this importance is expressed in the high number of the integration.

The fact that the integration of contemporary Korean-style houses is lower by more than 0.3 compared to traditional Korean houses, makes us question whether contemporary Korean-style houses express well the integrated spatial structure that traditional Korean houses contain. It is believed that the result, in which the integration of contemporary Korean-style houses is noticeably lower than traditional Korean houses despite having 30 fewer spaces, supports this kind of assertion. As another result of the analysis supporting this assertion, we point out that the integration of contemporary Korean-style houses shows a slightly lower result compared to that of contemporary architects' houses.

Summarising these analyses results, it cannot be said that the characteristics of the well integrated spatial configuration of traditional Korean houses are sufficiently reflected in contemporary Korean-style houses. Also, since it does not show a clear difference even in the comparison of integration with contemporary architects' houses, it is impossible to conclude that the expression of Koreanity was established as the architects intended in the aspect of spatial configuration.

\subsection{Analysis of spatial configuration by space usage}

For the analysis by classification of space usage, as in Table 7 , the spaces were divided into six types, such as the courtyard (inner courtyard, courtyard of the men's part of a house and back courtyard), main room (sitting room, reception room, bedroom such as a room opposite the bedroom, working room, library), living room (vestibule), utility room (kitchen, bathroom, toilet and laundry room), attachment room (warehouse, servants' quarters and garage) and corridor (narrow wooden porch, entrance hall, corridor and balcony). We calculated the mean of the factors, which are the spatial configurations of the three house types per 6 spaces of usage, which are shown in Tables 6,7 and 8. The mean of the global integration of each house group per usage of space is presented in Table 10.

In reviewing the spatial configuration factors of traditional Korean houses (Table 6), the courtyard has not only the biggest value of space, but also the highest values for the other configurational measurements compared to other space types. Global and local integrations show that direct access to all spaces is available from the courtyard, which presents the highest values even when compared to the houses of other types. This shows that the courtyard in traditional Korean houses is the easiest space to approach.

The analysis results in Table 9 showed that the courtyard mentioned and applied to express Koreanity in contemporary Korean-style houses has a significant gap (over 0.35 ) in the global integration with traditional Korean houses (with global 
integrations of $0.646383,0.927687$ respectively). These differences in the measurement of global integrations imply that the functional role of the courtyard in contemporary Korean-style houses is not established as much as the courtyard functions as a key element in the allocation of space in many traditional Korean houses.

Table 5. Classification of space by main use

\begin{tabular}{c|c|c|c|c|c}
\hline Courtyard & Main room & $\begin{array}{c}\text { Living room } \\
\text { (vestibule) }\end{array}$ & $\begin{array}{c}\text { Attachment } \\
\text { room }\end{array}$ & $\begin{array}{c}\text { Utility } \\
\text { room }\end{array}$ & Corridor \\
\hline $\begin{array}{c}\text { Inner } \\
\text { ourtyard, } \\
\text { courtyard } \\
\text { of men's } \\
\text { part of a } \\
\text { house, back } \\
\text { courtyard }\end{array}$ & $\begin{array}{c}\text { Bedroom, } \\
\text { working } \\
\text { room, } \\
\text { library }\end{array}$ & $\begin{array}{c}\text { Living } \\
\text { room, } \\
\text { vestibule }\end{array}$ & $\begin{array}{c}\text { Warehouse, } \\
\text { storage, } \\
\text { garage }\end{array}$ & $\begin{array}{c}\text { Kitchen, } \\
\text { toilet, } \\
\text { laundry } \\
\text { room }\end{array}$ & $\begin{array}{c}\text { Entrance, } \\
\text { entrance } \\
\text { hall, } \\
\text { balcony }\end{array}$ \\
\hline
\end{tabular}

Table 6. Spatial configuration factor (Mean) of traditional Korean houses

\begin{tabular}{c|c|c|c|c}
\hline $\begin{array}{c}\text { Traditional Korean } \\
\text { houses }\end{array}$ & $\begin{array}{c}\text { Number } \\
\text { of space }\end{array}$ & $\begin{array}{c}\text { Global } \\
\text { integration }\end{array}$ & $\begin{array}{c}\text { Local } \\
\text { integration }\end{array}$ & Spatial depth \\
\hline Courtyard & 281 & 0.989514 & 2.075839 & 5.282437 \\
\hline Main room & 269 & 0.878381 & 1.26936 & 5.678195 \\
\hline $\begin{array}{c}\text { Living room } \\
\text { (vestibule) }\end{array}$ & 213 & 0.954187 & 1.782119 & 5.345855 \\
\hline Attachment room & 50 & 0.776037 & 1.006336 & 6.488061 \\
\hline Utility room & 58 & 0.824947 & 1.233138 & 6.133553 \\
\hline Corridor & 136 & 0.955528 & 1.541518 & 5.565863 \\
\hline Mean & 84 & 0.927687 & 1.624474 & 5.548732 \\
\hline
\end{tabular}

Table 7. Spatial configuration factor (Mean) of contemporary Korean-style houses

\begin{tabular}{c|c|c|c|c}
\hline $\begin{array}{c}\text { Contemporary } \\
\text { Korean style houses }\end{array}$ & $\begin{array}{c}\text { Number } \\
\text { of space }\end{array}$ & $\begin{array}{c}\text { Global } \\
\text { integration }\end{array}$ & $\begin{array}{c}\text { Local } \\
\text { integration }\end{array}$ & Spatial depth \\
\hline Courtyard & 94 & 0.646383 & 1.344231 & 6.815064 \\
\hline Main room & 129 & 0.557782 & 1.127025 & 7.436045 \\
\hline $\begin{array}{c}\text { Living room } \\
\text { (vestibule) }\end{array}$ & 34 & 0.710634 & 1.493698 & 6.308299 \\
\hline Attachment room & 43 & 0.510679 & 0.823979 & 8.168466 \\
\hline Utility room & 78 & 0.603995 & 1.044138 & 6.995765 \\
\hline Corridor & 257 & 0.671076 & 1.440314 & 6.44114 \\
\hline Mean & 53 & 0.626277 & 1.274611 & 6.892536 \\
\hline
\end{tabular}

Table 8. Spatial configuration factor (Mean) of contemporary architects' houses

\begin{tabular}{c|c|c|c|c}
\hline $\begin{array}{c}\text { Contemporary } \\
\text { architects' houses }\end{array}$ & $\begin{array}{c}\text { Number } \\
\text { of space }\end{array}$ & $\begin{array}{c}\text { Global } \\
\text { integration }\end{array}$ & $\begin{array}{c}\text { Local } \\
\text { integration }\end{array}$ & Spatial depth \\
\hline Courtyard & 79 & 0.617979 & 1.152940 & 5.703080 \\
\hline Main room & 73 & 0.590360 & 1.161050 & 5.855701 \\
\hline $\begin{array}{c}\text { Living room } \\
\text { (vestibule) }\end{array}$ & 24 & 0.773346 & 1.745354 & 4.723214 \\
\hline Attachment room & 29 & 0.571687 & 0.785241 & 6.025751 \\
\hline Utility room & 66 & 0.577919 & 0.799518 & 6.080639 \\
\hline Corridor & 148 & 0.726415 & 1.506659 & 5.214934 \\
\hline Mean & 34.9 & 0.650854 & 1.232107 & 5.582925 \\
\hline
\end{tabular}

Table 9. Global integration: average of each house group per spatial use

\begin{tabular}{c|c|c|c}
\hline Space usage & $\begin{array}{c}\text { Traditional Korean } \\
\text { houses }\end{array}$ & $\begin{array}{c}\text { Contemporary } \\
\text { Korean style } \\
\text { houses }\end{array}$ & $\begin{array}{c}\text { Contemporary } \\
\text { architects' houses }\end{array}$ \\
\hline Courtyard & 0.989514 & 0.646383 & 0.617979 \\
\hline Main room & 0.878381 & 0.557782 & 0.590360 \\
\hline $\begin{array}{c}\text { Living room } \\
\text { (vestibule) }\end{array}$ & 0.954187 & 0.710634 & 0.773346 \\
\hline Attachment room & 0.776037 & 0.510679 & 0.571687 \\
\hline Utility room & 0.824947 & 0.603995 & 0.577919 \\
\hline Corridor & 0.955528 & 0.671076 & 0.726415 \\
\hline
\end{tabular}

The living room shows the highest global integration in contemporary Korean-style houses, and the difference with the courtyard is 0.064251 , while in traditional Korean houses it is -0.035327 and shows a difference of approximately 2 (Table 9). These differences indicate that the two types of houses have mutually different aspects in spatial configuration. That is, differences in global integrations between courtyard and vestibule space in traditional Korean houses are not clear compared to contemporary Korean-style houses. This means that the two kinds of space play a very important functional role in traditional Korean houses. However, in the case of contemporary Korean-style houses, the living room plays a more important functional role compared to the courtyard as it is about twice that of traditional Korean houses. This means that the courtyard has a more limited role in contemporary Korean-style houses than its role in traditional Korean houses.

Differences in the global integration between the courtyard and a living room (vestibule) are greater, since a living room in contemporary architects' houses is 0.155367 higher compared to the courtyard. It shows that the living room is more important than the courtyard in contemporary Korean-style houses. Unlike the spatial configuration of traditional Korean houses, which it is structured centred on a courtyard, the space in contemporary houses of the two kinds is allocated centred on a living room.

Changes from a courtyard-orientated spacial configuration to one that is living room-orientated are the result of periodic changes. This analysis makes us question whether the Koreanity of traditional Korean houses could not be realised from the aspect of courtyard-orientated spatial configuration, except in special cases. Even though the global integration of the courtyard in contemporary Korean-style houses was a little higher compared to contemporary architects' houses, contemporary architects' houses are slightly little higher if the mean of the global integration is compared to that of contemporary Korean-style house,s with values of 0.650854 and 0.626277 , respectively. These results also make it clear that we cannot conclude that Koreanity was realised in the aspect of spatial configuration as the intended by the architects.

Table 10 shows the spaces in the order of the largest global integration of the six usages per each house group. The order of the global integration per space usage of contemporary Korean-style houses and contemporary architects' houses is almost the same, except for one step difference regarding the utility rooms and main rooms. It directly denies the fact that it may be possible to confirm an aspect of Koreanity expressed in contemporary Korean-style houses if there is a significant difference in the spatial configuration 
between these two kinds of house.

Unlike the expectation that the spatial configuration between contemporary Korean-style houses and contemporary architects' houses may be different, no significant differences were confirmed. The order of the global integration of the corridor and attachment room is the same, and it can be understood that the two act as purely functional elements which are not sensitive to the needs of the changes of the period compared to other usages as the most basic element of house functions.

Table 10. Order of the largest global integration of the six usages per each house group

\begin{tabular}{c|c}
\hline $\begin{array}{c}\text { Traditional Korean } \\
\text { houses }\end{array}$ & $\begin{array}{c}\text { Courtyard }>\text { corridor }>\text { living room (vestibule) }>\text { Main } \\
\text { room }>\text { Utility room }>\text { Attachment room }\end{array}$ \\
\hline $\begin{array}{c}\text { Contemporary } \\
\text { Korean-style houses }\end{array}$ & $\begin{array}{c}\text { Living room (vestibule) } \\
>\text { corridor }>\text { Courtyard }>\text { Utility room }>\text { Main } \\
\text { room }>\text { Attachment room }\end{array}$ \\
\hline $\begin{array}{c}\text { Contemporary } \\
\text { architects' houses }\end{array}$ & $\begin{array}{c}\text { Living room (vestibule) }>\text { corridor }>\text { Courtyard }>\text { Main } \\
\text { room }>\text { Utility room }>\text { Attachment room }\end{array}$ \\
\hline
\end{tabular}

\section{CONCLUSION}

This research has implemented spatial configuration analysis for three types of house by utilising space syntax in order to answer questions that were suggested in prior research objectives, and the following results were obtained.

There were three main research objectives suggested. The first was to quantify the analysis results which could answer these questions: what characteristics of spatial configuration could be confirmed in traditional Korean upper class houses built during the Joseon Dynasty period? It was possible to confirm that the spatial configuration of traditional Korean houses was a structure in which the courtyard, as an external space of the houses, was a key space directly connecting other main rooms facing the courtyard. The space with the highest integration in Korean traditional architecture was the courtyard, and this is a reason for a very large difference when compared to the other two types of houses by maximising the mean of the integration of traditional Korean houses.

Besides the courtyard-orientated traditional Korean houses' spatial configuration, we found that the order of global integration value depended on the space usage. That is, it was possible to confirm that the characteristics, in which the topology (accessibility of the space) of the space was structured in the order of the spatial types of corridor, vestibule, main room, utility rooms and attachment rooms, with the courtyard being the highest. One thing to note was that the spatial configuration of traditional Korean houses had a higher integration of outdoor space such as the courtyard, corridor and vestibule or topology of half indoor and outdoor space than the indoor space such as sitting room, rooms across the main room, reception room and kitchen.

The spatial configuration characteristic of traditional Korean houses centring on outdoor or half indoor and outdoor space is believed to originate from the central role in the upper class houses, and must have been carried out within the community and society during that period. That is, for securing various functions of the houses required in the local society, in which a large patriarchal family is considered as important by society, and accessibility to all rooms within the house must have necessary and this means that the efficiency of space utilisation must have been achieved. This is a potential reason why the house management required for large family living had a more significant meaning in upper class houses during the Joseon Dynasty than just being the centre for resting and family living by a nuclear family unit, as required in contemporary houses.

The courtyard (or vestibule) is a very important element that improves accessibility not only for social functions but also as access to all spaces within the house. The courtyard was utilised as an element to maximise the efficiency of space utilisation of traditional Korean houses. These characteristics are inherent within the spatial configuration of traditional Korean houses and it can be said to be an element of spatial configuration for contemporary architects that is utilised for expressing Koreanity.

A main objective of this research was to verify whether such Koreanity was realised in contemporary Korean-style houses, in which this Koreanity was mentioned as the main design concept that the architect intended. In the analysis, the result of spatial configuration for these three types of house, the indices of all spatial configuration factors such as the integration or mean spatial depth, appeared to be very low in contemporary Korean-style houses. These changes in syntactic values can be interpreted to reflect that the house concept has changed from a house management system centring on a large family, into a relaxed living system centring on a nuclear family according to the flow of the era. These social changes also have changed the spatial configuration. That is, traditional Korean houses have a distributive type of spatial configuration centring on an outdoor courtyard, while contemporary Koreanstyle houses can be interpreted as a linear type of spatial configuration centring on an indoor living room.

The role of the courtyard, which was essential in traditional Korean houses of the past, was reduced drastically in contemporary Korean-style houses, and this was replaced by a living room of an indoor space. Spatial depth has become comparatively deeper as privacy is emphasised in contemporary Korean-style houses. The increase of this spatial depth appeared as a drop in the integration.

We know that syntactic values, such as integration, have little relationship with the size of space. It therefore does not impact on the integration, even if the number of spaces in a traditional Korean house is higher compared to contemporary Korean-style houses. Due to this, an objective comparison only becomes possible per house type or per space usage with the size of integration itself. The mean of the global integration of contemporary Korean-style houses showed a significant difference of over 0.3 as mentioned previously. This difference appeared more clearly in the comparison of the courtyard. If contemporary Korean-style houses have realized the Koreanity of traditional Korean houses in terms of spatial configuration, clearly a difference in the integration between them would not appear.

In particular, the role of the courtyard in contemporary Korean-style houses, the most mentioned element of Koreanity in contemporary Korean-style houses, is very small compared to traditional Korean houses. The protracted role of the courtyard becomes clearer in contemporary architects' houses. Room spaces of traditional Korean houses such as the sitting room or reception room have often been mentioned as another element of Koreanity 
in contemporary Korean-style houses. These main rooms have high integration next to the courtyard, corridor and vestibule in traditional Korean houses, but have lower values in contemporary Korean-style houses.

Despite these differences in syntactic properties, a very functional space such as corridor or attachment room appears to have the same order of integration for all house types. This is obvious as it is a function of a house that must be basically satisfied the despite changes in time periods.

Analysis results of these spatial configurations can only be interpreted in that Koreanity in contemporary Korean-style houses has been utilised in a more symbolic aspect than an actual functional aspect. The fact that the mean of the integration of contemporary Korean-style houses had no significant difference with that of contemporary architects' houses also supports this interpretation.

These configuration analyses allow us to realise that there is a noticeable difference between what the architects try to believe in what they tried to realise as a Koreanity design concept, and what they actually achieved through their designs of contemporary houses, at least in terms of spatial configuration. This research convinces us that the Koreanity residing in traditional Korean architecture needs to be incorporated more seriously, as well as tested more objectively, through their spatial designs.

\section{REFERENCES}

Chang, D. K. and Park, J. H. (2010) MoonSpacer"', Korea Copyright Commission, registration number: 201001129002116

Chang, D., Kim, Y., Moon, J., and Park, J. (2007) ArchiSpacer: Defining Space and Space Configuration. Proceedings of International Symposium on City Planning (ISCP). 299 308

Chang, Y. W. (2000) The spatial logic of traditional Korean settlements Hahoe and Yangdong villages by space syntax analysis. Master thesis. Inha University

Chun, B. H. (2002) Architectural cultural property of Korea, Jeonnam Province. Gimundang Publishing

Hanson, J. (1998) Decoding Homes and Houses. Cambridge University Press

Hillier, B. (1996) Space Is the Machine. Cambridge University Press. Huh, J. S. and Chung, Y. H. (2001) A Study on embodiment of Korean tradition of spatial composition of contemporary residence. Journal of The Korean Housing Association. 12(3), 21-28

Kang, Y. H. (1999) Architectural cultural property of Korea, Gyeongnam Province. Gimundang

Kim, H. M, (2000) Imgeodang (Bada series of architecture 3). Sigongsa

Kim, M. G. (2003) A Study on the Expression of Korean Traditional Characteristics in Contemporary Multi-housing Planning. PhD Thesis. Yonsei University

Korea Architects Association Edition (2005) Private house architecture 1, 2 (Korea Traditional Architecture No. 4 Collection). Bosunggak

Lee, B. H. (1998) The Typological Analysis of Space-Composition in the Traditional Korean Architecture. Journal of Architectural Institute of Korea. 14(2), 183-193
Lee, W. G. (1999) Architectural cultural property of Korea: Chungnam Province. Gimundang

Na, I. H. (2004) A Study on the Variation of the Interior Spatial Structure of Apartment House and Designed House. Master Thesis. Seoul National University

Noh, H. R. (2000) A Study on the Diachronic Transition of Korean Houses. PhD Thesis. Chungang University

Oh, S. O. (2007) A study on the characteristics of spaces with tradition of modern architecture for residence. Master thesis. Hongik University

Park, G. R. (1999) Architectural cultural property of Korea: Gangwon Province. Gimundang

Ryu, H. J. and Park, Y. S., (1999) A study on the traditionality in modern Korean houses of the 1990's designed by architects. Proceedings of the Korean Institute of Interior Design Conference. 1(1), 122-125

(Date of Submission : 2011.6.21) 